\title{
Comparative efficacy between rituximab versus conventional therapy and different dosage of rituximab in idiopathic membranous nephropathy
}

\author{
Miaomiao Chen ${ }^{1}$, Gaosi $\mathrm{Xu}^{1}$, and Xuexin $\mathrm{Chen}^{1}$ \\ ${ }^{1}$ Nanchang University Second Affiliated Hospital
}

March 16, 2021

\begin{abstract}
Abstract Objective: This study was to evaluate the efficacy of rituximab (RTX) versus conventional agents and different RTX dose regimens in the treatment of idiopathic membranous nephropathy (IMN). Methods: After systematically searched associated studies up to 1st December 2020, we performed a fixed and random-effects meta-analysis using the Stata software and evaluated the quality of included studies by the risk of bias scale of the Cochrane collaboration tool. Results: RTX had a higher total remission (TR) $(\mathrm{OR}=2.663,95 \% \mathrm{CI} 1.361$ to $5.210, \mathrm{P}=0.004)$ than conventional therapy for patients at moderate risk for lose of kidney function (pre-study proteinuria $<8 \mathrm{~g} / \mathrm{d}$ ), however, for patients at severe risk (pre-study proteinuria $>8$ $\mathrm{g} / \mathrm{d})$, there was no significant difference in TR ( $\mathrm{OR}=0.691,95 \%$ CI 0.064 to $7.423, \mathrm{P}=0.761)$. In RTX dose studies, standard dose regimen had a better effect of reducing proteinuria than low-dose regimen (Low dose MD $=-3.999,95 \%$ CI -6.177 to -1.820 ; standard dose $\mathrm{MD}=-5.220,95 \% \mathrm{CI}-7.160$ to $-3.279, \mathrm{P}<0.0001)$. Significant improvement in serum albumin was seen in patients treated with standard dose than low dose regimen (Low dose $\mathrm{MD}=0.601,95 \%$ CI 0.052 to 1.150, $\mathrm{P}=0.032$; standard dose $\mathrm{MD}=0.963,95 \%$ CI 0.740 to $1.185, \mathrm{P}<0.0001$ ). Conclusion: For patients with moderate risk IMN, RTX treatment has a higher TR than conventional therapy. Standard dose RTX is more effective than low dose in reducing proteinuria and recovering serum albumin levels.
\end{abstract}

\section{Introduction}

Idiopathic membranous nephropathy (IMN) is an immune-mediated disease with subepithelial immune complex deposition and glomerular basement membrane changes [1]. Patients are mainly manifested by proteinuria, hypoproteinemia, hypertension, and edema [2]. The auto-antigens like M-type phospholipase A2 receptor (PLA2R) [3] and thrombospondin type 1 domain containing 7A (THSD7A) [4] can be detected in most MN patients. As surrogates of immunologic activity, PLA2R and THSD7A provide a new direction for the diagnosis and treatment of IMN [5].

The treatment of IMN is always controversial. Most patients with MN and non-nephrotic proteinuria are sensitive to supportive therapy which includes angiotensin-converting-enzyme (ACE) inhibitors and angiotensinreceptor blockers (ARBs) [6]. However, in patients with the highest risk of disease progression and the decrease of proteinuria is seldom $>30 \%$ from pretreatment value, It mainly used alkylating agents and calcineurin inhibitors in treatment [7, 8]. Alkylating agent (mainly cyclophosphamide) is usually used for high-risk patients who failed to respond to 6-month supportive therapy [9] and can effectively prevent IMN from ESRD and death. Calcineurin inhibitors (mainly tacrolimus) can improve therapeutic effects and reduce toxicity to achieve the purpose of reducing the rate of proteinuria and renal function loss [9-12]. However, the efficacy of cyclophosphamide and tacrolimus in IMN treatment has controversy.

RTX is an anti-CD20 monoclonal antibody [13] that targets to trigger B cell to death through apoptosis $[14,15]$, complement-mediated cytotoxicity [16], and antibody-dependent cellular cytotoxicity [17, 18]. The 
efficacy of RTX as initial treatment is similar to traditional immunosuppressants treatment (alkylating agents plus steroid combination therapy and calcineurin inhibition therapy) [19-21]. The standard protocol of RTX for $\mathrm{MN}$ is intravenous injection of $375 \mathrm{mg} / \mathrm{m}^{2}$ every week for 4 weeks, or two doses of $1000 \mathrm{mg}$ infusions 2 weeks apart or $1 \times 375 \mathrm{mg} / \mathrm{m}^{2}$ intravenously at a 14-day interval [22, 23]. Since the ideal RTX dosage and the long-term side effects of a larger cumulative dose are unknown, and some studies have demonstrated the effectiveness of low-dose regimens versus conventional dosage (standard protocol or two doses of RTX (500 mg each) ) [22], nephrologists argued for the use of low doses of RTX (B cell-driven treatment or the dose of RTX is $1 \times 375 \mathrm{mg} / \mathrm{m}^{2}$ or $2 \times 375 \mathrm{mg} / \mathrm{m}^{2}$ or $100 \mathrm{mg}$ of RTX or two doses of RTX (500 $\mathrm{mg}$ each) infusion 7 days apart).

Compared to KDIGO (Kidney Disease: Improving Global Outcomes) 2012 guidelines, KDIGO 2020 guidelines emphasize the role of RTX in patients with a moderate (pre-study proteinuria greater than $3.5 \mathrm{~g} / \mathrm{d}$ and less than $8 \mathrm{~g} / \mathrm{d}$ ) and high (pre-study proteinuria more than $8 \mathrm{~g} / \mathrm{d}$ ) risk of IMN, but evidence regarding the efficacy and safety of RTX in MN treatment remains elusive [9, 24]. There is still not meta-analysis that can provide evidence of the RTX therapeutic advantages by stratifying inclusion studies based on the risk of progression of renal function loss in patients. At the same time, the efficacy of different doses of RTX is controversial and uncertain. To guide the clinical use of RTX, this article used statistical methods to summarize several studies on MN treatment with RTX or conventional therapy and explore the therapeutic effect of different RTX dosages (low dose versus standard dose).

\section{Methods}

\subsection{Data sources and searches}

We systematically searched the randomized controlled trials (RCTs), clinical studies, and cohort studies on the efficacy and safety of RTX in the treatment of adult MN from Pubmed, Web of Science, Cochrane Library, Embase, ScienceDirect, and SinoMed from inception until 1 December 2020. Additional articles come from the references of reviews, meta-analyses, systematic reviews, reports, and guidelines. All these articles are English. The appropriate keywords and medical subject headings in logical combinations we used included "Rituximab", "Rituximab CD20 Antibody", "Mabthera", "IDEC-C2B8 Antibody", "Rituxan", "GP2013", "Membranous Nephropathy" "Membranous Glomerulonephritides", "Primary Membranous Nephropathy", "Idiopathic Membranous Glomerulonephritis" and "Heymann Nephritis".

\subsection{Inclusion and exclusion criteria}

The inclusion criteria contains: a)RCTs, cohort studies, clinical trials, case-control study, and single-center experience; b)All patients in the selected studies were confirmed to have IMN by renal biopsy. Each patient was older than 18 years old, and c) Outcome events and remission (CR or/and PR) need to be reported. The CR was defined as proteinuria $<0.3 \mathrm{~g} /$ day accompanied by a normal serum albumin concentration and normal serum creatinine (Scr). The PR was defined as proteinuria $<3.5 \mathrm{~g} /$ day and a $50 \%$ or greater reduction from peak values, accompanied by an improvement or normalization of the serum albumin concentration and stable Scr. The study needs to evaluate the efficacy of RTX in patients for at least 6 months.

The exclusion criteria contains: a) Any review articles, books, and documents, meta-analysis, meeting records, case reports, ongoing research, and other non-randomized studies were excluded; b) The results of the study were related to the use of RTX in patients with secondary MN or other patients with non-MN, and c) The study looked at RTX in combination with other unsupportive agents for MN.

\subsection{Data extraction and quality assessment}

Two independent reviewers reviewed the original study reports and sifted and extracted the data. Data includes the type of study, time of publication, author, region or country, study duration, intervention, and control. Additionally, reviewers also extracted demographic, clinical, immunological, and pathological variables of patients. Outcome data is also extracted from the study articles by the observers, mainly including CR, PR, TR. Quality assessment is carried out through the Cochrane Collaboration's tool. If 
there is a disagreement between two independent reviewers about the data, then the independent reviewers should discuss and reach a consensus.

\subsection{Data analysis}

To analyze whether RTX has an advantage over other conventional therapies in the treatment of MN, this meta-analysis using the Stata software (Stata Corporation, Texas, USA). In subgroup analysis, patients are grouped according to their pre-study proteinuria. RTX dose is used as a variable for the analysis of the therapeutic effect of MN. Inconsistency index $\left(I^{2}\right)$ statistics are used to analyze the heterogeneity of the included studies. To analyze the endpoints of TR, we choose the Mantel-Haenszel method of the random effects model and applied effect index odds ratio (OR), this is because significant heterogeneity $\left(P<0.1\right.$ or $I^{2}$ $>50 \%$ ) exists in included studies. To analyze the effects of different doses of RTX on Scr, proteinuria and ALB after treatment, we used the invariance fixed-effect method and invariance random effect method and selected the mean difference (MD) as the continuous outcome. Score statistics and precise binomial method were used to calculate $95 \%$ CI for effect sizes. STATA/MP-14 software was used for all data analysis. And all 2 -sided $P<0.05$ was considered to indicate statistical significance.

\section{Results}

\subsection{Description of included trials}

A total of 1675 relevant pieces of literature were identified in this paper through a database search (Figure. 1), including 281 pieces from Pubmed, 565 pieces from Web of Science, 73 pieces from Cochrane Library, 550 pieces from Embase, 82 pieces from Science Direct, 124 pieces from SinoMed. The Endnote software was used to remove 1102 repeated articles between different databases. Two inspectors removed reviews, Case reports, Meta-analysis, and Off-topic types. Finally, six articles [25-30] were included in the study comparing the therapeutic advantages of RTX with conventional therapy. Twelve studies [30-42] were included in the efficacy studies of different doses of RTX. The studies provided information on 643 patients. Baseline data characteristics of the included studies are summarized in Table 1 and Table 2, respectively.

\subsection{Quality assessment}

We assessed the quality of the included studies by Cochrane Handbook and assessed the quality of the included studies by giving "author judgments" of "low risk" or "unclear risk" or "high risk" for different types of offset evaluation entries. The results showed that most of the included studies were low-risk or unclear risk related to the offset items, indicating that the quality of the included studies in this paper was good.

\subsection{Efficacy of RTX compared with other therapeutic agents in MN (Totally remission)}

Forest plots (Figure. 2) show the overall and subgroup efficacy and safety of RTX in the treatment of MN compared to conventional agents. Six articles reported TR and all RTX regimens are uniform dosages $(4 \times 375$ $\left.\mathrm{mg} / \mathrm{m}^{2}\right)$. The included studies showed that there is no significant difference in TR $(\mathrm{OR}=1.659,95 \%$ CI 0.668 to $4.119, I^{2}$ of $61.9 \%$ indicating heterogeneity, $P=0.275$ ) for MN with RTX compared to conventional therapy. In the subgroup analysis, for patients with pre-study proteinuria $<8 \mathrm{~g} / \mathrm{d}$, RTX had a higher TR $\left(\mathrm{OR}=2.663,95 \%\right.$ CI 1,361 to $5.210, I^{2}$ of $0.0 \%$ indicating heterogeneity, $\left.P=0.004\right)$ than conventional therapy, however, for patients with pre-study proteinuria $>8 \mathrm{~g} / \mathrm{d}$, there was no significant difference in TR $\left(\mathrm{OR}=0.691,95 \%\right.$ CI 0.064 to $7.423, I^{2}$ of $83.3 \%$ indicating heterogeneity, $\left.P=0.761\right)$.

\subsection{Effect of RTX dose on the therapeutic of IMN}

\subsubsection{Proteinuria (g/24 hour)}

The post-treatment proteinuria index was evaluated in twelve studies (Figure. 3A). Results of meta-analysis showed RTX significantly reduced proteinuria (MD $=-4.885,95 \%$ CI -6.340 to $-3.370, I^{2}$ of $69.2 \%$ indicating heterogeneity, $P<0.0001)$ in patients with MN. In the subgroup analysis, low-dose RTX was not effective than conventional dosage of RTX in reducing proteinuria (Low dose MD $=-3.999,95 \%$ CI -6.177 to $-1.820, I^{2}$ 
of $33.3 \%$ indicating heterogeneity, $P<0.0001$; standard dose MD $=-5.220,95 \%$ CI -7.160 to $-3.279, I^{2}$ of $78.4 \%$ indicating heterogeneity, $P<0.0001)$.

\subsubsection{Serum albumin $(\mathrm{g} / \mathrm{L})$}

There are eleven articles reported the lever of ALB (Figure. 3B), which shows that RTX treatment was associated with a statistically significant increase in ALB (MD $=0.884,95 \%$ CI 0.740 to $1.185, I^{2}$ of $72.0 \%$ indicating heterogeneity, $P<0.0001)$. In the subgroup analysis, low dose RTX improved ALB $(\mathrm{MD}=0.601$, $95 \%$ CI 0.052 to $1.150, I^{2}$ of $83.2 \%$ indicating heterogeneity, $P=0.032$ ). However, RTX can be more significantly in increasing ALB (MD $=0.963,95 \%$ CI 0.740 to $1.185, I^{2}$ of $53.7 \%$ indicating heterogeneity, $P$ $<0.0001)$ in the standard dose subgroup.

\subsubsection{Serum creatinine $(\mathrm{mg} / \mathrm{dL})$}

Scr at the end of treatment was reported in nine articles (Figure. 4). Treatment with RTX led to no significant reduction Scr $\left(\mathrm{MD}=-0.027,95 \%\right.$ CI -0.196 to $0.142, I^{2}$ of $48.8 \%$ indicating heterogeneity, $P=$ 0.758). In subgroup analyses, both low dose RTX and standard dose RTX did not significantly reduce Scr (Low dose MD $=0.110,95 \%$ CI -0.050 to $0.271, I^{2}$ of $0.0 \%$ indicating heterogeneity, $P=0.177$. Standard dose $\mathrm{MD}=-0.176,95 \% \mathrm{CI}-0.456$ to $0.103, I^{2}$ of $56.5 \%$ indicating heterogeneity, $\left.P=0.216\right)$.

\section{Discussion}

Recently, the clinical application of RTX in treating IMN has been gradually improved. In KDIGO 2012 guideline, RTX is not recommended for the primary treatment of IMN. The guidelines suggest that glucocorticoids combined with alkylating agents are the first choice, and the Italian protocol is recommended. Calcineurin inhibitors are recommended for those unsuitable for Italian protocol $[9,10]$. While in the KDIGO 2020 guideline, RTX is recommended for patients with a high risk of progression to ERSD after 6 months of CNIs treatment, except the patients with loss of PLA2R antibodies after CNIs treatment [24]. It is a symbol that the position of RTX in the treatment of MN has improved, and RTX may be a more efficient and safe option.

Although some meta-analysis papers on RTX for IMN have been published resently[43-45], They provide no evidence of the superiority of RTX over other conventional treatments. This article compared RTX with conventional therapy in IMN treatment and inclusion studies were stratified according to patients' pre-treatment proteinuria level. In a subgroup analysis, RTX showed a greater advantage in patients with moderate risk IMN. That's probably because, for patients with proteinuria $>8 \mathrm{~g} / \mathrm{d}$, more severe glomerular injury causes some drug-protein molecules to be lost from the glomerular filtration membrane, so RTX cannot form effective drug concentration and play a therapeutic role, which leads the high-risk patients had a lower TR after RTX treatment. RTX is expected to become the first-line drug in MN treatment. In a study from Dahan et al. [46], patients were randomly assigned to 6-month therapy with nonimmunosuppressive antiproteinuric treatment (NIAT) and $375 \mathrm{mg} / \mathrm{m}^{2}$ intravenous RTX on days 1 and 8 or NIAT alone. The results show that at 6 months, 13 patients in the NIAT-RTX group and 8 patients in the NIAT group achieved remission. During the observational phase, TR rates before the change of assigned treatment were 24 of $37(64.9 \%)$ and 13 of $38(34.2 \%)$ patients in NIAT-RTX and NIAT groups, respectively. Data from Fervenza et al. [47] also confirmed that RTX was more effective than conventional therapy in improving the remission of IMN. However, van den Brand et al. [28] have published a study claiming that the cumulative incidence of PR was lower in the RTX group, rates of CR and the composite renal endpoint did not differ significantly between groups (RTX vs. steroid plus cyclical cyclophosphamide).

Different dosages of RTX have been successfully used in IMN treatment [20, 25], but the ideal dosage regimen and long-term adverse effects of a high dosage of RTX remain controversial. Traditional RTX is $375 \mathrm{mg} / \mathrm{m}^{2}$ once weekly for 4 weeks, or $1000 \mathrm{mg}$ RTX on day 1 and day 15 (short protocols) [23]. Some clinicians also use B cell-driven treatment which gives a second course routinely according to the B cell counts (when B cell [?] 5/ $\mathrm{mm}^{3}$ ) [31, 48]. Remuzzi et al. [49] demonstrated that low-dose therapy is also effective as standard protocol and has the characteristics of no serious adverse reactions [32]. However, in 2017, Moroni 
et al. [34] published a study showing that low-dose RTX obtains remission in $<50 \%$ of IMN patients, which means low-dose RTX is poorly effective in IMN treatment. Some studies have also found that a higher dose RTX protocol is more effective on the depletion of B-cells and lacking epitope spreading is associated with the remission of IMN [50]. In this article, six low-dose therapy and six standard treatment researches about RTX were included, and subgroup analysis was divided into two groups according to the RTX dosage. mMeta-analysis results showed that not only the low dose RTX but the standard dose can reduce the level of proteinuria (Low dose regimen $\mathrm{MD}=-3.99$, standard dose regimen $\mathrm{MD}=-5.22$ ) in patients. However, the standard dose RTX regimen was better than the low dose RTX regimen in reducing proteinuria. We also reported the effect of different doses of RTX on the recovery of Scr and ALB levels. The results showed that the standard dose of RTX could significantly improve the ALB levels after treatment. Different doses of RTX do not affect the remission of Scr. Despite the high cost of RTX treatment, to better improve the remission of IMN and repress recurrence, a standard dose regimen will be a better choice for IMN patients.

There are also some defects in this paper. In the study of the comparison of RTX and traditional therapies for remission, most of the included studies are from western countries, and the sample size is small. Due to the lack of specific information about adverse events, CR, PR and PLA2R provided in the included studies, we were unable to made the evidence of the paper adequate.

In conclusion, this is the first paper comparing the efficacy of rituximab versus conventional therapy and different dosage of rituximab in IMN. Based on the results from the above meta-analysis study, the efficiency of RTX is superior to that of other immunosuppressants in IMN. In terms of reducing proteinuria and restoring ALB, standard dose regimens were more advantageous than low-dose regimens. Although this paper demonstrates the superiority of RTX and the advantage of standard dose RTX in IMN treatment, more clinical studies are needed for further confirmation.

\section{Acknowledgements}

This work was supported by the National Natural Science Foundation of China (81970583 \& 82060138) and the Natural Science Foundation of Jiangxi Province (20181BAB205016 \& 20202BABL206025).

\section{Disclosures}

None

\section{References}

1. Sethi, S., New 'Antigens' in Membranous Nephropathy. J Am Soc Nephrol, 2021. 32 (2): p. 268-278.

2. JONES, D., Nephrotic glomerulonephritis. The American journal of pathology, 1957. 33 (2): p. 313-29.

3. Beck, L.H., Jr., et al., M-type phospholipase A2 receptor as target antigen in idiopathic membranous nephropathy. N Engl J Med, 2009. 361 (1): p. 11-21.

4. Tomas, N.M., et al., Thrombospondin type-1 domain-containing 7A in idiopathic membranous nephropathy. N Engl J Med, 2014.371 (24): p. 2277-2287.

5. Ronco, P. and H. Debiec, Membranous nephropathy: current understanding of various causes in light of new target antigens. Curr Opin Nephrol Hypertens, 2021.

6. Schieppati, A., et al., Nonimmunosuppressive therapy of membranous nephropathy. Seminars in Nephrology, 2003. 23 (4): p. 333-339.

7. Gansevoort, R.T., et al., Antiproteinuric drugs in patients with idiopathic membranous glomerulopathy. Nephrol Dial Transplant, 1992. 7 Suppl 1 : p. 91-6.

8. Kosmadakis, G., et al., Comparison of the influence of angiotensin-converting enzyme inhibitor lisinopril and angiotensin II receptor antagonist losartan in patients with idiopathic membranous nephropathy and nephrotic syndrome. Scand J Urol Nephrol, 2010.44 (4): p. 251-6. 
9. Mizuno, T., et al., KDIGO (Kidney Disease: Improving Global Outcomes) criteria could be a useful outcome predictor of cisplatin-induced acute kidney injury. Oncology, 2012. 82 (6): p. 354-9.

10. Tran, T.H., et al., Overview of current and alternative therapies for idiopathic membranous nephropathy. Pharmacotherapy, 2015.35 (4): p. 396-411.

11. De Vriese, A.S., et al., A Proposal for a Serology-Based Approach to Membranous Nephropathy. Journal of the American Society of Nephrology, 2017. 28 (2): p. 421-430.

12. Cattran, D.C. and P.E. Brenchley, Membranous nephropathy: integrating basic science into improved clinical management. Kidney Int, 2017. 91 (3): p. 566-574.

13. Vacchi, C., et al., Efficacy and safety of rituximab in the treatment of connective tissue disease-related interstitial lung disease. Drugs Context, 2021. 10 .

14. Semac, I., et al., Anti-CD20 therapeutic antibody rituximab modifies the functional organization of rafts/microdomains of B lymphoma cells. Cancer Res, 2003. 63 (2): p. 534-40.

15. Bonavida, B., Rituximab-induced inhibition of antiapoptotic cell survival pathways: implications in chemo/immunoresistance, rituximab unresponsiveness, prognostic and novel therapeutic interventions. Oncogene, 2007. 26 (25): p. 3629-36.

16. Manches, O., et al., In vitro mechanisms of action of rituximab on primary non-Hodgkin lymphomas. Blood, 2003.101 (3): p. 949-54.

17. Wang, S.Y., et al., NK-cell activation and antibody-dependent cellular cytotoxicity induced by rituximabcoated target cells is inhibited by the C3b component of complement. Blood, 2008.111 (3): p. 1456-63.

18. Roccatello, D., et al., New insights into immune mechanisms underlying response to Rituximab in patients with membranous nephropathy: A prospective study and a review of the literature.Autoimmun Rev, 2016. 15 (6): p. 529-38.

19. Ponticelli, C., et al., A 10-year follow-up of a randomized study with methylprednisolone and chlorambucil in membranous nephropathy. Kidney Int, 1995. 48 (5): p. 1600-4.

20. Ruggenenti, P., et al., Rituximab in idiopathic membranous nephropathy. J Am Soc Nephrol, 2012. 23 (8): p. 1416-25.

21. Cravedi, P., et al., Efficacy and safety of rituximab second-line therapy for membranous nephropathy: a prospective, matched-cohort study. Am J Nephrol, 2011. 33 (5): p. 461-8.

22. Roccatello, D., R. Fenoglio, and S. Sciascia, Efficacy of low or standard dose rituximab as compared to Ponticelli's regimen in membranous nephropathy. Nephrology Dialysis Transplantation, 2019.34 : p. a123.

23. Ruggenenti, P., F.C. Fervenza, and G. Remuzzi, Treatment of membranous nephropathy: time for a paradigm shift. Nat Rev Nephrol, 2017. 13 (9): p. 563-579.

24. KDIGO 2020 Clinical Practice Guideline for Diabetes Management in Chronic Kidney Disease. Kidney Int, 2020. 98 (4s): p. S1-s115.

25. Dahan, K., et al., Rituximab for Severe Membranous Nephropathy: A 6-Month Trial with Extended Follow-Up. J Am Soc Nephrol, 2017. 28 (1): p. 348-358.

26. Seitz-Polski, B., et al., Phospholipase A2 Receptor 1 Epitope Spreading at Baseline Predicts Reduced Likelihood of Remission of Membranous Nephropathy. J Am Soc Nephrol, 2018. 29 (2): p. 401-408.

27. Rosenzwajg, M., et al., B-and T-cell subpopulations in patients with severe idiopathic membranous nephropathy may predict an early response to rituximab. Kidney Int, 2017. 92 (1): p. 227-237.

28. van den Brand, J., et al., Safety of Rituximab Compared with Steroids and Cyclophosphamide for Idiopathic Membranous Nephropathy. J Am Soc Nephrol, 2017. 28 (9): p. 2729-2737. 
29. Fervenza, F.C., et al., Rituximab or Cyclosporine in the Treatment of Membranous Nephropathy. N Engl J Med, 2019.381 (1): p. 36-46.

30. Fenoglio, R., et al., Efficacy of low or standard rituximab-based protocols and comparison to Ponticelli's regimen in membranous nephropathy. J Nephrol, 2020.

31. Cravedi, P., et al., Titrating rituximab to circulating B cells to optimize lymphocytolytic therapy in idiopathic membranous nephropathy. Clinical journal of the American Society of Nephrology : CJASN, 2007. 2 (5): p. 932-937.

32. Sugiura, H., et al., Effect of single-dose rituximab on primary glomerular diseases. Nephron Clin Pract, 2011. 117 (2): p. c98-105.

33. Ramachandran, R., et al., CD19 Targeted Low-Dose Rituximab Is Effective in the Management of Refractory Phospholipase A2 Receptor Antibody-Associated Membranous Nephropathy. Kidney Int Rep, 2017.2 (1): p. 89-90.

34. Moroni, G., et al., Low-dose rituximab is poorly effective in patients with primary membranous nephropathy. Nephrol Dial Transplant, 2017. 32 (10): p. 1691-1696.

35. Remuzzi, G., et al., Rituximab for idiopathic membranous nephropathy. Lancet, 2002. 360 (9337): p. 923-4.

36. Ruggenenti, P., et al., Rituximab for idiopathic membranous nephropathy (IMN): Renal biopsy findings predict response to treatment.Journal of the American Society of Nephrology, 2003. 14 : p. 528A-528A.

37. Ruggenenti, P., et al., Rituximab for idiopathic membranous nephropathy: who can benefit? Clin J Am Soc Nephrol, 2006.1 (4): p. 738-48.

38. Fervenza, F.C., et al., Response to 'rituximab in membranous nephropathy'. Kidney International, 2008. 74 (3): p. 392-392.

39. Fervenza, F.C., et al., Rituximab treatment of idiopathic membranous nephropathy. Kidney International, 2008. 73 (1): p. 117-125.

40. Fervenza, F.C., et al., Rituximab Therapy in Idiopathic Membranous Nephropathy: A 2-Year Study. Clinical Journal of the American Society of Nephrology, 2010. 5 (12): p. 2188-2198.

41. Busch, M., et al., Rituximab for the second-and third-line therapy of idiopathic membranous nephropathy: a prospective single center study using a new treatment strategy. Clin Nephrol, 2013.80 (2): p. 105-13.

42. Bagchi, S., et al., Low-dose Rituximab therapy in resistant idiopathic membranous nephropathy: singlecenter experience. Clin Kidney J, 2018. 11 (3): p. 337-341.

43. Huang, L., et al., Rituximab for the management of idiopathic membranous nephropathy: a meta-analysis. Int Urol Nephrol, 2020.

44. Zhang, J., et al., Efficacy and safety of rituximab therapy for membranous nephropathy: a meta-analysis. Eur Rev Med Pharmacol Sci, 2018. 22 (22): p. 8021-8029.

45. Lu, W., et al., Efficacy and safety of rituximab in the treatment of membranous nephropathy: A systematic review and meta-analysis. Medicine (Baltimore), 2020. 99 (16): p. e19804.

46. Dahan, K., et al., Rituximab for Severe Membranous Nephropathy: A 6-Month Trial with Extended Follow-Up. Journal of the American Society of Nephrology, 2017. 28 (1): p. 348-358.

47. Fervenza, F.C., et al., A Multicenter Randomized Controlled Trial of Rituximab versus Cyclosporine in the Treatment of Idiopathic Membranous Nephropathy (MENTOR). Nephron, 2015. 130 (3): p. 159-68.

48. Ruggenenti, P., P. Cravedi, and G. Remuzzi, Rituximab for membranous nephropathy and immune disease: less might be enough. Nat Clin Pract Nephrol, 2009. 5 (2): p. 76-7. 
49. Remuzzi, G., et al., Rituximab for idiopathic membranous nephropathy. Lancet, 2002.360 (9337): p. 923-924.

50. Seitz-Polski, B., et al., High-Dose Rituximab and Early Remission in PLA2R1-Related Membranous Nephropathy. Clin J Am Soc Nephrol, 2019. 14 (8): p. 1173-1182.

Table 1 Characteristics of the studies on the comparison of RTX and traditional therapies for remission included in the analysis.

\begin{tabular}{|c|c|c|c|c|c|c|c|c|}
\hline Study & Region & $\begin{array}{l}\text { Study } \\
\text { design }\end{array}$ & Sex & Sex & $\begin{array}{l}\text { Age } \\
\text { (yrs) }\end{array}$ & Treatment & $\begin{array}{l}\text { Study } \\
\text { Dura- } \\
\text { tion } \\
(\mathrm{mo})\end{array}$ & Proteinuria \\
\hline $\begin{array}{l}\text { Dahan } \\
2016\end{array}$ & France & $\mathrm{RCT}$ & $\begin{array}{l}\text { Male } \\
\mathrm{T}: 28 \mathrm{C}: \\
24\end{array}$ & $\begin{array}{l}\text { Female } \\
\text { T: } 9 \text { C: } 14\end{array}$ & $\begin{array}{l}\text { T: } 53.0 \\
(42.0-63.0) \\
\text { C: } 58.5 \\
(43.0-64.0)\end{array}$ & $\begin{array}{l}\text { T: } \\
\text { NIAT+RTX } \\
\text { C: NIAT }\end{array}$ & 23 & $\begin{array}{l}\text { T: } 7680.0 \\
(4584.3- \\
10399.0) \\
\text { C: } 7195.1 \\
(5363.1- \\
8965.1)\end{array}$ \\
\hline $\begin{array}{l}\text { Seitz- } \\
\text { Polski } \\
2017\end{array}$ & France & $\mathrm{RCT}$ & $\begin{array}{l}\text { T: } 23 \mathrm{C}: \\
19\end{array}$ & T: 6 C: 10 & $\begin{array}{l}\text { T: } 52.0 \\
(41.0-63.0) \\
\text { C: } 59.0 \\
(44.0-63.0)\end{array}$ & $\begin{array}{l}\text { T: RTX } \\
\text { C: NIAT }\end{array}$ & 23 & $\begin{array}{l}\mathrm{T}: 7.4 \\
(6.2-9.0) \\
\mathrm{C}: 8.4 \\
(4.4-11.0)\end{array}$ \\
\hline $\begin{array}{l}\text { Rosenzwajg } \\
2017\end{array}$ & France & $\mathrm{RCT}$ & T: 16 C: 9 & $\mathrm{~T}: 16 \mathrm{C}: 9$ & $\begin{array}{l}\text { T: } 57.0 \\
(26.0-74.0) \\
\text { C: } 57.0 \\
(26.0-74.0)\end{array}$ & $\begin{array}{l}\text { T: } \\
\text { NIAT+RTC } \\
\text { C: NIAT }\end{array}$ & 6 & $\begin{array}{l}\text { T: } 7590 \\
(3440.0- \\
11000.0) \\
\text { C: } 6250 \\
(3170.0- \\
15900.0)\end{array}$ \\
\hline $\begin{array}{l}\text { van den } \\
\text { Brand } \\
2017\end{array}$ & Italy & $\begin{array}{l}\text { Prospective } \\
\text { cohort } \\
\text { study }\end{array}$ & $\begin{array}{l}\text { T: } 72 \mathrm{C}: \\
76\end{array}$ & $\begin{array}{l}\text { T: } 28 \mathrm{C}: \\
27\end{array}$ & $\begin{array}{l}\mathrm{T}: \\
51.5 \pm 15.9 \\
\mathrm{C}: \\
55.3 \pm 12.7\end{array}$ & $\begin{array}{l}\text { T: RTX } \\
\text { C: } \\
\text { steroid+ } \\
\text { cyclical } \\
\text { CYC }\end{array}$ & 40 & $\begin{array}{l}\text { T: } 6400 \\
(4400.0- \\
8894.0) \mathrm{C}: \\
8840 \\
(5651.0- \\
11660.0)\end{array}$ \\
\hline $\begin{array}{l}\text { Fervenza } \\
2019\end{array}$ & Canada & $\mathrm{RCT}$ & $\begin{array}{l}\mathrm{T}: 47 \mathrm{C}: \\
53\end{array}$ & $\begin{array}{l}\mathrm{T}: 18 \mathrm{C}: \\
12\end{array}$ & $\begin{array}{l}\mathrm{T}: \\
51.9 \pm 12.6 \\
\mathrm{C}: \\
52.2 \pm 12.4\end{array}$ & $\begin{array}{l}\text { T: RTX } \\
\text { C: CYC }\end{array}$ & 24 & $\begin{array}{l}\text { T: } 8.9 \\
(6.8-12.3) \\
\text { C: } 8.9 \\
(6.7-12.9)\end{array}$ \\
\hline $\begin{array}{l}\text { Fenoglio } \\
\text { (SD) } 2020\end{array}$ & Italy & $\begin{array}{l}\text { Retrospective } \\
\text { case- } \\
\text { control } \\
\text { study }\end{array}$ & eT: 9 C: 8 & $\mathrm{~T}: 6 \mathrm{C}: 6$ & $\begin{array}{l}\mathrm{T}: \\
61.4 \pm 11.5 \\
\mathrm{C}: \\
67.1 \pm 17.5\end{array}$ & $\begin{array}{l}\text { T: RTX } \\
\text { C: } \\
\text { Ponticelli } \\
\text { Protocol* }^{*}\end{array}$ & 24 & $\begin{array}{l}\text { T: } 5.1 \pm 1.4 \\
\text { C: } 8.3 \pm 4.8\end{array}$ \\
\hline
\end{tabular}

Abbreviations: yrs, years;mo, month;RCT, randomize controlled trials;T, treatment group; C, control group; NIAT, 6 months of nonimmunosuppressive antiproteinuric treatment; RTX, rituximab; SD, standerd dose (lymphoma protocol, four $375 \mathrm{mg} / \mathrm{m}^{2}$ weekly doses of RTX).

*Data are shown as median (IQR)

*Ponticelli Protocol, Ponticelli's regimen (glucocorticoids and cyclophospamide). 
Table 2 Characteristic of studies on the comparison of low dose RTX and standard protocol.

\begin{tabular}{|c|c|c|c|c|c|c|c|c|}
\hline Study & Region & $\begin{array}{l}\text { Study } \\
\text { design }\end{array}$ & Sex & Sex & $\begin{array}{l}\text { Age } \\
(\text { yrs })\end{array}$ & $\begin{array}{l}\text { Study } \\
\text { dura- } \\
\text { tion } \\
\text { (mo) }\end{array}$ & $\begin{array}{l}\text { RTX } \\
\text { admin- } \\
\text { istra- } \\
\text { tion }\end{array}$ & $\begin{array}{l}\text { Protei } \\
\text { prior } \\
\text { to } \\
\text { RTX }\end{array}$ \\
\hline & & & Male & Female & & & & \\
\hline $\begin{array}{l}\text { Cravedi } \\
2007\end{array}$ & Italy & $\begin{array}{l}\text { Matched- } \\
\text { cohort } \\
\text { study }\end{array}$ & 8 & 4 & $57.0 \pm 13.0$ & 12 & $\begin{array}{l}\text { B cell- } \\
\text { driven } \\
\text { treatment* }\end{array}$ & $10.3 \pm 8$ \\
\hline $\begin{array}{l}\text { Sugiura } \\
2010\end{array}$ & Japan & $\begin{array}{l}\text { Prospective } \\
\text { clinical } \\
\text { trial }\end{array}$ & 2 & 2 & $66.5 \pm 8.7$ & 6 & $\begin{array}{l}1 \times 375 \\
\mathrm{mg} / \mathrm{m}^{2} \\
(\mathrm{n}=4) \\
(\operatorname{maxi}- \\
\text { mum } \\
500 \mathrm{mg})\end{array}$ & $4.3 \pm 2.6$ \\
\hline \multicolumn{2}{|c|}{$\begin{array}{l}\text { RamachandranIndia } \\
2016\end{array}$} & $\begin{array}{l}\text { Prospective } \\
\text { clinical } \\
\text { trial }\end{array}$ & - & - & - & 6 & $\begin{array}{l}100 \mathrm{mg} \\
\text { of RTX } \\
(\mathrm{n}=6)\end{array}$ & $12.1 \pm 10$ \\
\hline $\begin{array}{l}\text { Moroni } \\
2017\end{array}$ & Italy & $\begin{array}{l}\text { Prospective } \\
\text { single- } \\
\text { center } \\
\text { experience }\end{array}$ & 23 & 11 & $52.8 \pm 15.2$ & 24 & $\begin{array}{l}1 \times 375 \\
\mathrm{mg} / \mathrm{m}^{2}(\mathrm{n} \\
=18) \\
2 \times 375 \\
\mathrm{mg} / \mathrm{m}^{2}(\mathrm{n} \\
=16)\end{array}$ & $11.9 \pm 8$ \\
\hline $\begin{array}{l}\text { Bagchi } \\
2018\end{array}$ & India & $\begin{array}{l}\text { Multicentric } \\
\text { retro- } \\
\text { spective } \\
\text { study }\end{array}$ & 14 & 7 & $33.3 \pm 12.3$ & 12 & $\begin{array}{l}\text { two } \\
\text { doses of } \\
\text { RTX } \\
\text { (500mg } \\
\text { each) } \\
\text { infusion } \\
7 \text { days } \\
\text { apart }\end{array}$ & $6.2 \pm 2.2$ \\
\hline $\begin{array}{l}\text { Fenoglio } \\
(\mathrm{LD}) \\
2020\end{array}$ & Italy & $\begin{array}{l}\text { Prospective } \\
\text { cohort } \\
\text { experience }\end{array}$ & 5 & 9 & $64.4 \pm 10.8$ & 24 & $\begin{array}{l}1 \times 375 \\
\mathrm{mg} / \mathrm{m}^{2} \\
(\mathrm{n}=14)\end{array}$ & $7.5 \pm 4.8$ \\
\hline $\begin{array}{l}\text { Remuzzi } \\
2002\end{array}$ & Italy & $\begin{array}{l}\text { Prospective } \\
\text { single- } \\
\text { center } \\
\text { experience }\end{array}$ & 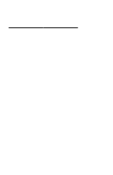 & 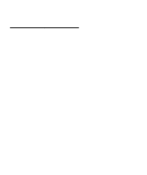 & $50.1 \pm 45.6$ & 20 & $\begin{array}{l}4 \times 375 \\
\mathrm{mg} / \mathrm{m}^{2}\end{array}$ & $8.6 \pm 1.5$ \\
\hline $\begin{array}{l}\text { Ruggenenti } \\
2003\end{array}$ & Italy & $\begin{array}{l}\text { Prospective } \\
\text { single- } \\
\text { center } \\
\text { experience }\end{array}$ & 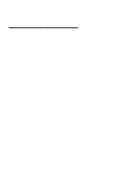 & - & $52.5 \pm 19.6$ & 12 & $\begin{array}{l}4 \times 375 \\
\mathrm{mg} / \mathrm{m}^{2}\end{array}$ & $8.6 \pm 4.2$ \\
\hline $\begin{array}{l}\text { Ruggenenti } \\
\text { (pro) } \\
2006\end{array}$ & Italy & $\begin{array}{l}\text { Retrospective } \\
\text { cohort } \\
\text { and } \\
\text { prospec- } \\
\text { tive } \\
\text { cohort }\end{array}$ & 4 & 5 & $51.2 \pm 13.2$ & 12 & $\begin{array}{l}4 \times 375 \\
\mathrm{mg} / \mathrm{m}^{2}\end{array}$ & $8.9 \pm 5.3$ \\
\hline
\end{tabular}




\begin{tabular}{|c|c|c|c|c|c|c|c|c|}
\hline Study & Region & $\begin{array}{l}\text { Study } \\
\text { design }\end{array}$ & Sex & Sex & $\begin{array}{l}\text { Age } \\
(\text { yrs })\end{array}$ & $\begin{array}{l}\text { Study } \\
\text { dura- } \\
\text { tion } \\
(\mathrm{mo})\end{array}$ & $\begin{array}{l}\text { RTX } \\
\text { admin- } \\
\text { istra- } \\
\text { tion }\end{array}$ & $\begin{array}{l}\text { Protei } \\
\text { prior } \\
\text { to } \\
\text { RTX }\end{array}$ \\
\hline $\begin{array}{l}\text { Fervenza } \\
2008\end{array}$ & Canada & $\begin{array}{l}\text { Prospective } \\
\text { single- } \\
\text { center } \\
\text { experience }\end{array}$ & 13 & 2 & $47.0 \pm 8.0$ & 12 & $\begin{array}{l}4 \times 375 \\
\mathrm{mg} / \mathrm{m}^{2}\end{array}$ & $13.0 \pm 5$ \\
\hline $\begin{array}{l}\text { Fervenza } \\
2010\end{array}$ & Canada & $\begin{array}{l}\text { Prospective } \\
\text { single- } \\
\text { center } \\
\text { experience }\end{array}$ & 17 & 3 & $48.6 \pm 12.9$ & 24 & $\begin{array}{l}4 \times 375 \\
\mathrm{mg} / \mathrm{m}^{2}\end{array}$ & $11.9 \pm 4$ \\
\hline $\begin{array}{l}\text { Busch } \\
2013\end{array}$ & Germany & $\begin{array}{l}\text { Prospective } \\
\text { single- } \\
\text { center } \\
\text { experience }\end{array}$ & 10 & 4 & $47.0 \pm 14.0$ & 12 & $\begin{array}{l}4 \times 375 \\
\mathrm{mg} / \mathrm{m}^{2}\end{array}$ & $8.6 \pm 1$. \\
\hline
\end{tabular}

Abbreviations: yrs, years; mo, month; RTX, rituximab; LD, low dose; pro, only use prospective cohort study material.

*B cell driven treatment, a single dose then an additional dose if there were greater than 5 circulating $\mathrm{B}$ cells per cubic millimeter on the morning after the first dose.

\section{Hosted file}

Table.pdf available at https://authorea.com/users/401877/articles/513843-comparativeefficacy-between-rituximab-versus-conventional-therapy-and-different-dosage-ofrituximab-in-idiopathic-membranous-nephropathy

\section{Hosted file}

Figure.pdf available at https://authorea.com/users/401877/articles/513843-comparativeefficacy-between-rituximab-versus-conventional-therapy-and-different-dosage-ofrituximab-in-idiopathic-membranous-nephropathy 

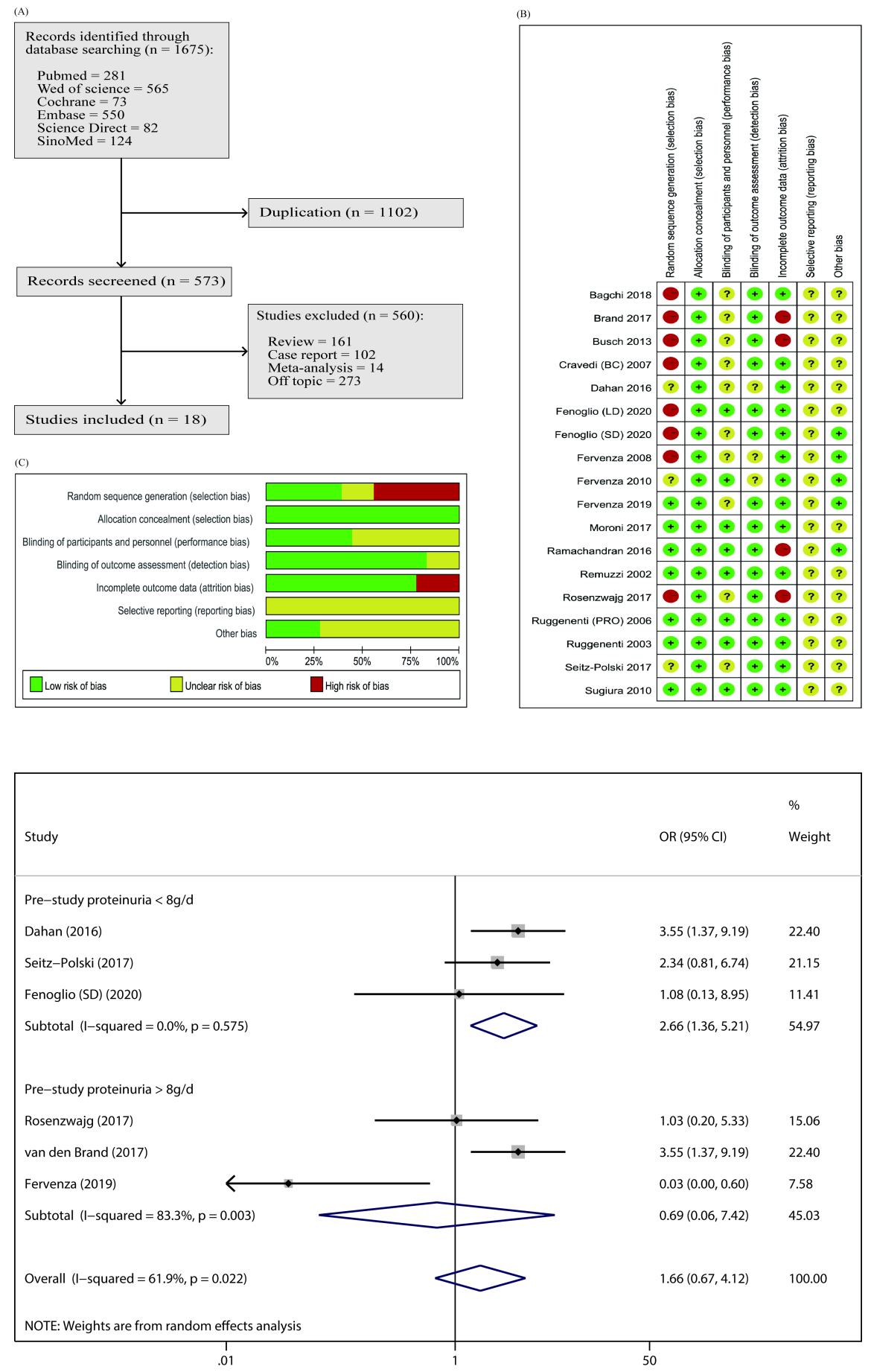


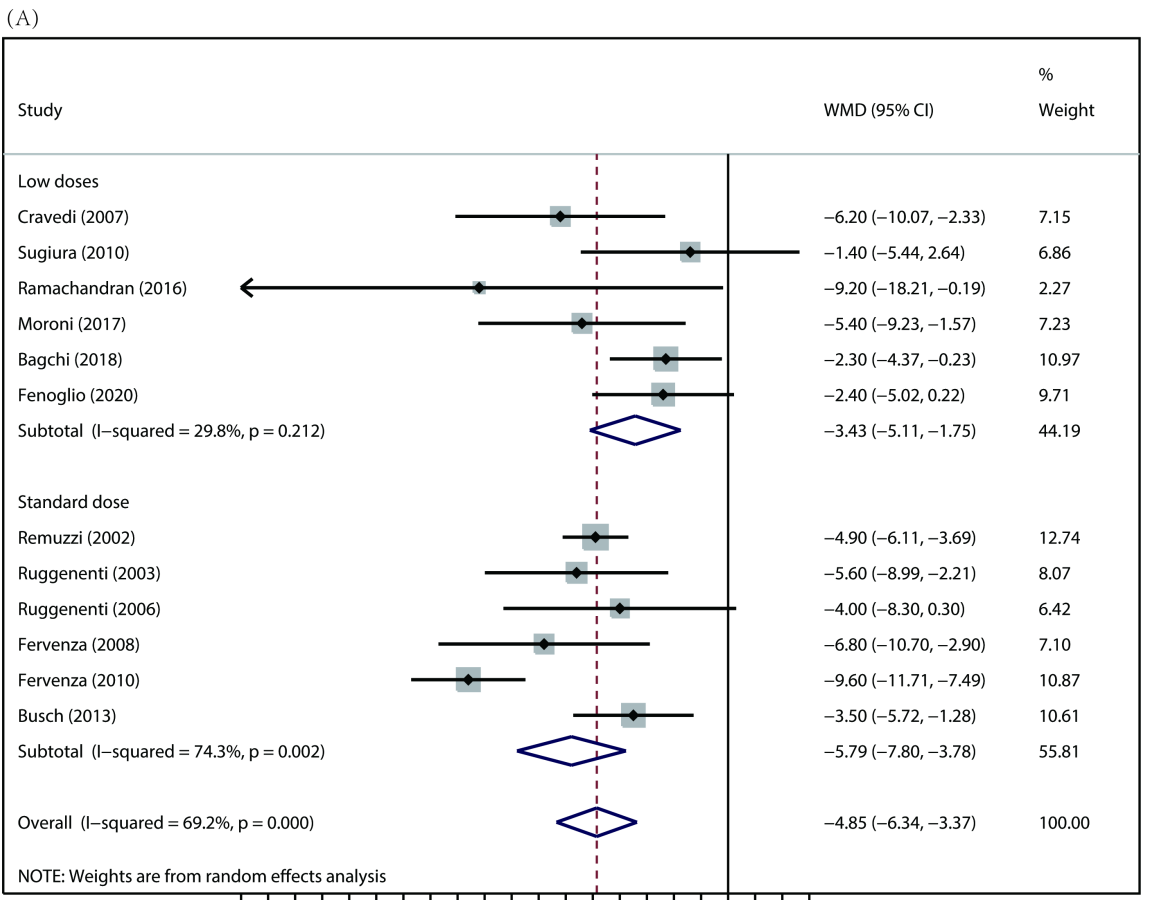

NOTE: Weights are from random effects analysis

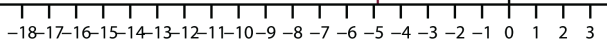

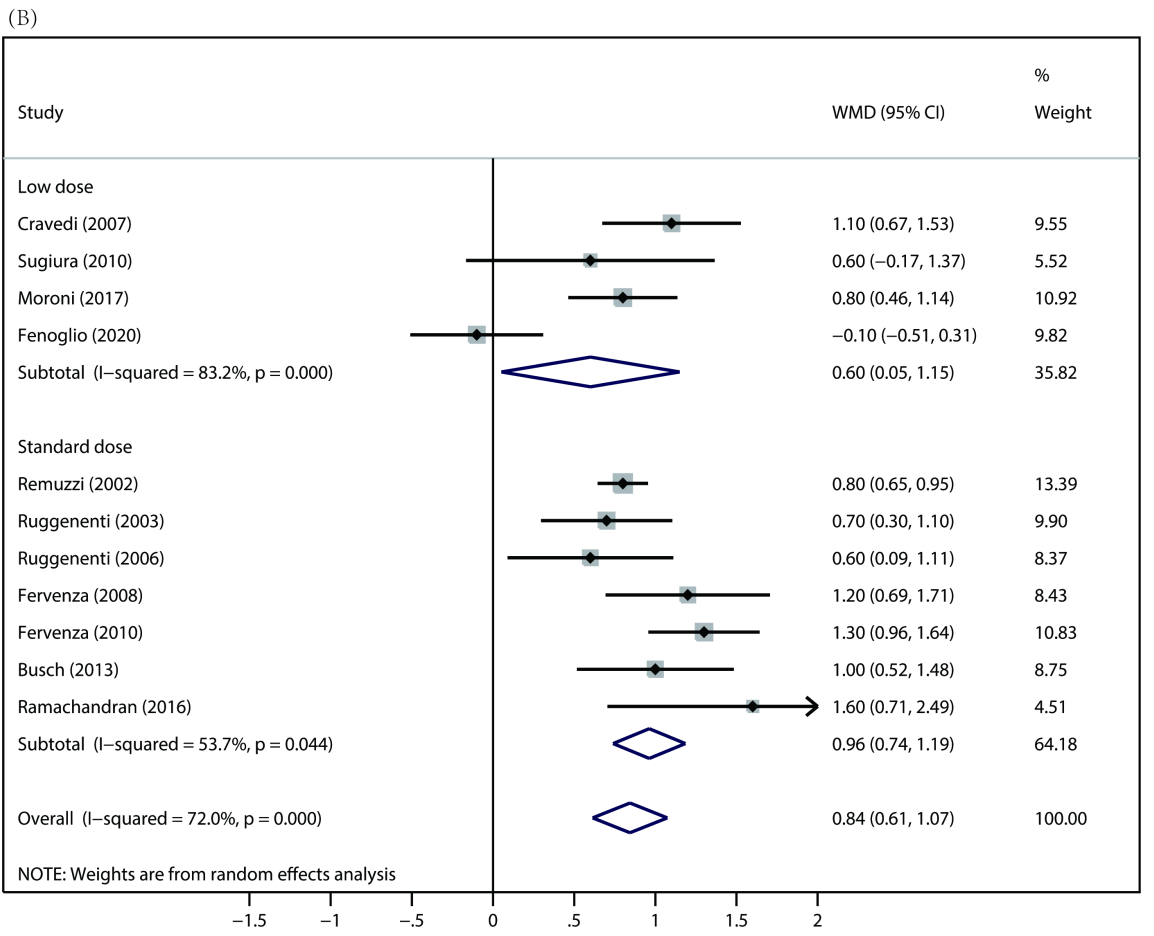




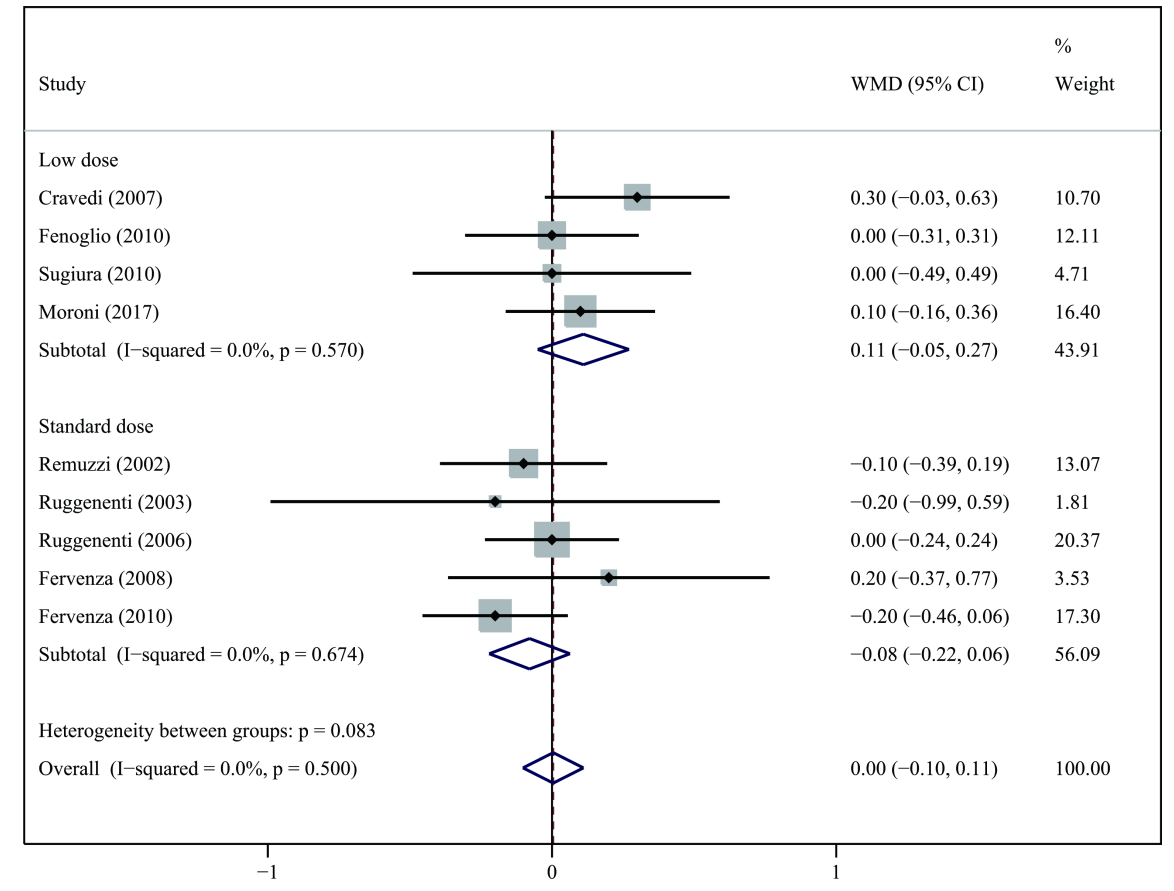

